\title{
Gas exchanges and mineral content of corn crops irrigated with saline water ${ }^{1}$
}

\author{
Valdécio dos Santos Rodrigues ${ }^{2 *(D)}$, Geocleber Gomes de Sousa ${ }^{3}$, Stallone da Costa Soares ${ }^{2}$, \\ Kelly Nascimento Leite ${ }^{4}$ Emanuel D'Araújo Ribeiro de Ceita ${ }^{5}$, José Thomas Machado de Sousa ${ }^{3}$
}

10.1590/0034-737X202168050010

\begin{abstract}
Inferior quality water can be used by agricultural producers in arid and semi-arid regions due to the lower availability of good-quality water. Therefore, the objective was to identify the influence of irrigation with saline water on gas exchange and leaf contents in corn (Zea mays L.) crop. The work was conducted in the field, in the experimental area of the Experimental Farm of the University of International Integration of Afro-Brazilian Lusofonia (UNILAB), RedençãoCE. The experimental design used in the research was randomized blocks, with five treatments: $1.0 ; 2.0 ; 3.0 ; 4.0$ and 5.0 $\mathrm{dS} \mathrm{m} \mathrm{m}^{-1}$ and four repetitions. At 45 days after sowing (DAS) the gas exchange variables were evaluated: transpiration, stomatal conductance, photosynthesis, internal $\mathrm{CO}_{2}$ concentration, water use efficiency and leaf temperature. And at 110 DAS the contents of $\mathrm{N}, \mathrm{P}, \mathrm{K}, \mathrm{Ca}$ and $\mathrm{Mg}$ in plant leaves. The saline stress due to saltwater irrigation leads to a reduction in photosynthesis, stomatal conductance, internal $\mathrm{CO}_{2}$ concentration and transpiration in field maize plants. Salt stress reduces the levels of N, P, K, Ca and Mg mineral elements in maize leaves.
\end{abstract}

Keywords: saline stress; gas exchange; mineral content; Zea mays L.

\section{INTRODUCTION}

The corn crop is used as a food source and for energy production. It is an important source of food and income for many semi-arid producers. It is a C4 plant with high photosynthetic rates (Taiz et al. 2017), however, the photosynthetic process acts through light energy present in the leaves, acting in the formation of carbohydrates, which are allocated to the vegetative and reproductive organs (Gomes et al. 2011).

Irrigation is a technique that has contributed most to the increase in food production, however, inefficient management, often practiced by farmers, associated with climatic conditions can increase the amount of salts deposited in the soil, affecting the germination of seeds, initial plant growth and finally crop yield (Freire et al. 2018, Sousa et al. 2017; Cruz et al., 2021).

Noteworthy, salinity can causes decrease in the osmotic potential and mineral nutrition of plants (Dias et al., 2018;
Sousa et al., 2021), in physiological indices (Pereira Filho et al., 2019), stomatal closure, low assimilation of $\mathrm{CO}_{2}$, and reduces photosynthesis in thylakoid membranes of chloroplasts (Taiz et al., 2017).

Corn is considered moderately sensitive to salinity, that is, this crop has a water threshold salinity of $1.1 \mathrm{dS} \mathrm{m}^{-1}$, and soil of $1.7 \mathrm{dS} \mathrm{m}^{-1}$, being more sensitive to salt stress in the vegetative period and showing greater tolerance during the flowering season (Ayers \& Westcot, 1999).

Assessing the initial growth of corn, Sousa et al. (2016) found that salt stress negatively affected physiological variables such as photosynthesis and sweating. In addition, Omoto et al. (2012) in corn plants, concluded that there was a reduction in gas exchange, inducing a decrease in photosynthetic metabolites due salt stress.

Saline stress will affect gas exchange and the levels of mineral elements in corn grown under field conditions.

\footnotetext{
Submitted on September $11^{\text {th }}, 2019$ and accepted on April 15 th, 2021.

'This work is part of the first author's master's dissertation, and it was funded by Fundação Cearense de Apoio ao Desenvolvimento Científico e Tecnológico (FUNCAP).

${ }^{2}$ Universidade Federal do Paraná, Departamento de Solos e Engenharia Agrícola, Curitiba, Paraná, Brazil. valdeciorodrigues@hotmail.com; stallonesoares@hotmail.com;

${ }^{3}$ Universidade da Integração Internacional da Lusofonia Afro-Brasielira, Redenção, Ceará, Brazil. Sousagg@ @nilab.edu.br; thssousa2015@gmail.com

${ }^{4}$ Universidade Federal do Acre, Cruzeiro do Sul, Acre, Brazil. knleite.ufac@gmail.com.

${ }_{5}^{5}$ Universidade Estadual Paulista "Júlio de Mesquita Filho", Jaboticabal, São Paulo, Brazil. emanueldeceita@gmail.com

"Corresponding author: valdeciorodrigues@ hotmail.com
} 
Therefore, the aim of this study was to evaluate the effect of irrigation water in different salt concentrations on gas exchange and leaf contents in maize plants.

\section{MATERIAL AND METHODS}

The experiment was carried out in the experimental area of the University of International Integration of AfroBrazilian Lusophony (UNILAB), Redenção, Ceará. According to Alvares et al. (2013) the region's climate is of the BSh' type, very hot temperature, with rains prevailing in the summer and autumn seasons. The region where the experiment was conducted has an average air temperature of $26{ }^{\circ} \mathrm{C}$, an average relative humidity of $71.3 \%$ and an average annual precipitation of $1,086 \mathrm{~mm}$. Rainfall during the experimental phase was $11 \mathrm{~mm}$, relative humidity of $70.41 \%$ and temperature of $27.3^{\circ} \mathrm{C}$.

To evaluate the chemical analysis of the soil in the experimental area, samples were collected at a depth of 20 $\mathrm{cm}$, (Table 1) following the methodology described by Texeira et al. (2017). The soil was characterized as sandy loam with density of $1.3 \mathrm{~kg} \mathrm{dm}^{-3}$, electrical conductivity of the saturation extract (ECse) of $0.23 \mathrm{dS} \mathrm{m}^{-1}$, and hydrogenation potential $(\mathrm{pH})=6$.

The work was developed in a randomized block experimental design, with the following treatments: five levels of salinity of the irrigation water $(1.0 ; 2.0 ; 3.0 ; 4.0$ and $5.0 \mathrm{dS}$ $\mathrm{m}^{-1}$ ) and four repetitions.

The spacing used during sowing (four seeds per hole) was $1.0 \mathrm{~m}$ between planting lines and $0.3 \mathrm{~m}$ between plants.

The thinning was carried out eight days after sowing (DAS), leaving one plant per hole in a total of 20 plants for each 6 meter plot, that is, presenting a planting density of 33,333 plants $^{-1}$. In the same period, irrigations with water of different saline levels were started. During the experiment phase (10 DAS) the different saline levels were applied and calculated based on the reference evapotranspiration (ET0) and the crop coefficient (Kc) (Doorenbos \& Kassam 1994), estimated by the class " $A$ " tank method, with a two day watering shift.

The saline waters were prepared using the methodology described in Rhoades et al. (2000), that is, using the salts of $\mathrm{NaCl}, \mathrm{CaCl}_{2} \cdot 2 \mathrm{H}_{2} \mathrm{O}$ and $\mathrm{MgCl}_{2} \cdot 6 \mathrm{H}_{2} \mathrm{O}$, in $7: 2: 1$ proportion, in non saline water $\left(0.25 \mathrm{dS} \mathrm{m}^{-1}\right)$, obeying the relationship between the electrical conductivity of water $(\mathrm{ECw})$ and its concentration ( $\left.\mathrm{mmol}_{\mathrm{c}} \mathrm{L}^{-1}=\mathrm{CEx} 10\right)$, according to Rhoades et al. (2000). Drip irrigators with a flow rate of $8 \mathrm{~L} \mathrm{~h}^{-1}$, spaced at $0.60 \mathrm{~m}$, i.e. a dripper for 2 plants, and the coefficient of uniformity of distribution (CUD) was evaluated and detected $90 \%$.

The irrigation time was estimated under Equation 1:

$\mathrm{It}=\frac{E T c \times D s}{E a \times q} \times 60$

In which: It = Irrigation time $(\mathrm{min}) ; \mathrm{ET}_{\mathrm{c}}=$ crop evapotranspiration $(\mathrm{mm})$; Ds = drip spacing; Ea = Efficiency of application (0.9) and $\mathrm{q}=$ flow $\left(\mathrm{L} \mathrm{h}^{-1}\right)$. A leaching fraction of 0.15 was added to the slide to be applied (Ayers \& Westcot, 1999).

At 45 days after sowing (DAS), corresponding to the beginning of the reproductive phase, the following variables were evaluated: photosynthesis (A), transpiration (E), stomatal conductance ( $\mathrm{gs}), \mathrm{CO}_{2}$ internal concentration $(\mathrm{Ci})$, foliar temperature $\left(\mathrm{T}_{\mathrm{f}}\right)$, and water use efficiency (WUE) (under the quotient (A/E)).

The measurements of the values of the physiological variables were performed using an infrared gas analyzer (LCi System, ADC, Hoddesdon, UK), between 10 am and $11 \mathrm{am}$, using an artificial radiation source (about 1,200 $\mu \mathrm{mol}$ $\left.\mathrm{m}^{-2} \mathrm{~s}^{-1}\right)$.

At the end of the maize crop cycle (110 DAS), dry samples (leaf limbs) were collected and placed in paper bags, and identified as the treatments adopted. Then they were ground in a Wiley-type mill and nitrogen $(\mathrm{N})$ contents determined by extracts prepared by sulfur digestion by the micro-Kjeldahl method (Tedesco et al., 1995). In order to determine the potassium $(\mathrm{K})$, calcium $(\mathrm{Ca})$ and magnesiumin $(\mathrm{Mg})$ and phosphorus $(\mathrm{P})$ content were conducted flame photometry and photocolorimetry, respectively (Malavolta et al., 1997).

Data were submitted to analysis of variance and regression, and means were compared by Tukey test with $\mathrm{p}<0.05$, using the Assistat 7.7 Beta program (Silva \& Azevedo 2009).

\section{RESULTS AND DISCUSSION}

According to mean square values, there was a significant influence $(\mathrm{p} \leq 0.01)$ and $(\mathrm{p} \leq 0.05)$ by the $\mathrm{F}$ test for all studied variables (Table 2).

The salt stress inhibited photosynthesis (Figure 1A), with the quadratic polynomial model being the best adjusted

Table 1: Chemical characterization of the soil used before maize sowing and application of treatments

\begin{tabular}{|c|c|c|c|c|c|c|c|c|c|c|c|}
\hline \multicolumn{12}{|c|}{ Chemical attributes } \\
\hline$\overline{\mathrm{OM}}$ & $\mathbf{N}$ & $\mathbf{P}$ & $\mathbf{K}^{+}$ & $\mathrm{Ca}^{2+}$ & $\mathbf{M g}^{2+}$ & $\mathrm{Na}^{+}$ & $\mathbf{H}^{+}+\mathrm{Al}^{3+}$ & Al & SB & $\mathbf{T}$ & $\mathbf{V}$ \\
\hline & & $\left(\mathrm{mg} \mathrm{kg}^{-1}\right)$ & & & & & $\left(\mathrm{cmol}_{\mathrm{c}} \mathrm{kg}^{-1}\right)$ & & & & $(\%)$ \\
\hline 16.96 & 0.92 & 8 & 0.3 & 2.7 & 2.1 & 0.03 & 1.82 & 0.05 & 5.1 & 7 & 73 \\
\hline
\end{tabular}

OM, Organic matter; SB, sum of bases; T, cation exchange capacity; V, base saturation.

Rev. Ceres, Viçosa, v. 68, n.5, p. 453-459, sep/oct, 2021 
Table 2: Summary of variance analysis for the variables stomatal conductance (gs), photosynthesis (A), transpiration (E), foliar temperature (Tf), internal $\mathrm{CO}_{2}$ concentration (Ci) and water use efficiency (WUE) in maize plants irrigated with salt water

\begin{tabular}{lccccccc}
\hline \multirow{2}{*}{$\mathbf{S V}$} & $\mathbf{D F}$ & \multicolumn{9}{c}{ Mean square } \\
\cline { 3 - 8 } & & $\mathbf{g s}$ & $\mathbf{A}$ & $\mathbf{E}$ & $\mathbf{T}_{\mathbf{f}}$ & $\mathbf{C i}$ & WUE \\
\hline Blocks & 3 & $0.001^{\text {ns }}$ & $2.19^{\text {ns }}$ & $0.031^{\text {ns }}$ & $1.41^{\text {ns }}$ & $60.28^{\text {ns }}$ & $0.01^{\text {ns }}$ \\
Treatment & 4 & $0.008^{*}$ & $59.37^{* *}$ & $1.46^{* *}$ & $17.75^{* *}$ & $1407.63^{* *}$ & $4.14^{*}$ \\
Residue & 12 & 0.001 & 2.85 & 0.8 & 0.24 & 19.7 & 0.09 \\
Total & 19 & & & & & & \\
\hline GM & & 0.27 & 32.22 & 5.61 & 31.85 & 156.69 & 5.74 \\
\hline CV $(\%)$ & 16.07 & 5.24 & 5.05 & 1.55 & 2.83 & 540 \\
\hline
\end{tabular}

SV, source of variation; DF, degree of freedom; GM, general mean; CV, coefficients of variation; ${ }^{\text {ns }}$, not significant; $* *$ and $*$ Significant at 0.01 and 0.05 by the $\mathrm{F}$ test, respectively.
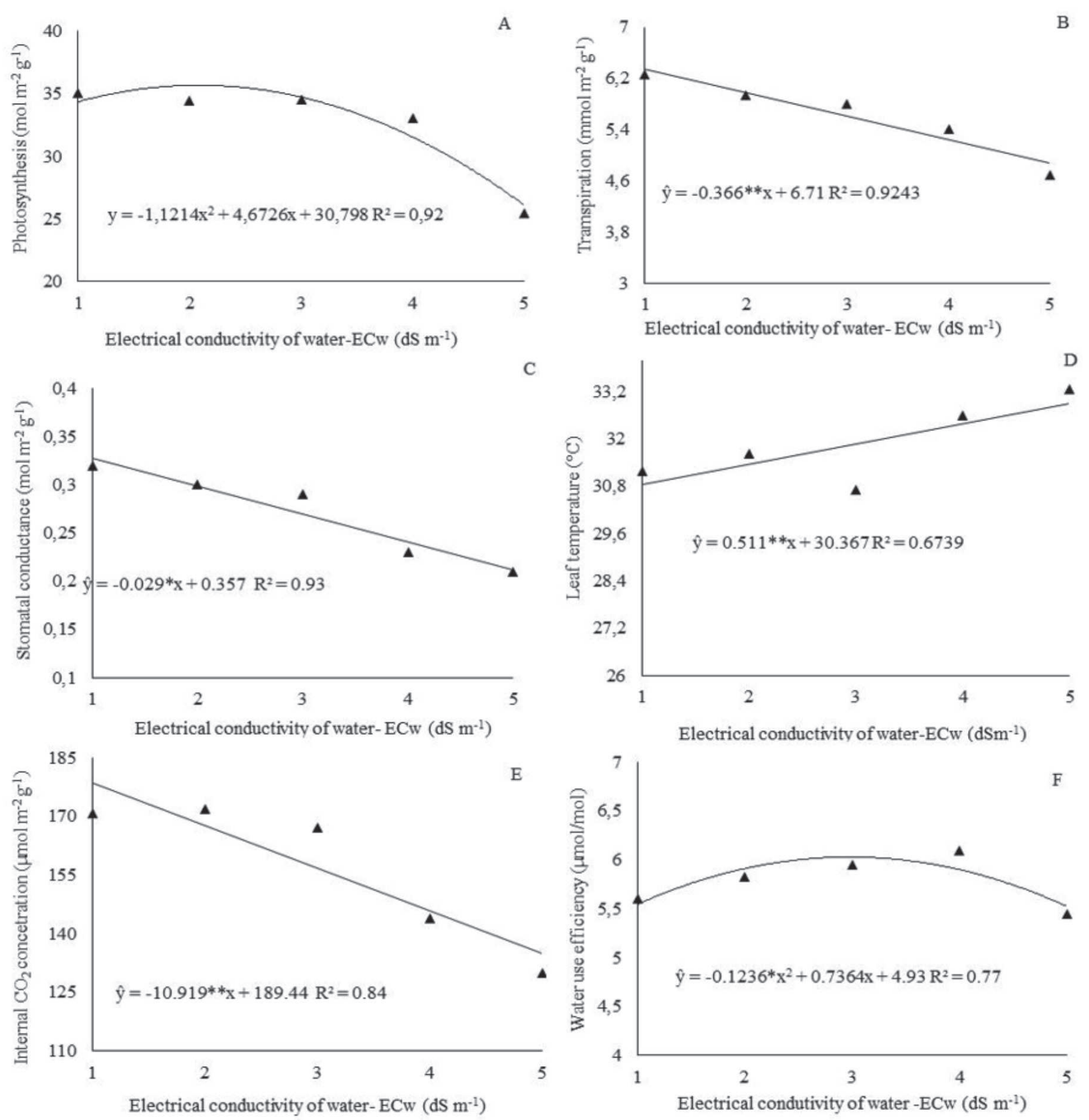

Figure 1: Photosynthesis, transpiration, Stomatal condutctance, leaf temperature, internal $\mathrm{CO}_{2}$ concentration and water use efficiency in maize plants irrigated with saline waters at 45 DAS. 
to the data, with maximum values of $35.6 \mathrm{~mol} \mathrm{~m}^{-2} \mathrm{~g}^{-1}$ for an electrical conductivity of the water of $2.08 \mathrm{dS} \mathrm{m}^{-1}$. These effects are associated to the osmotic, toxic, and nutritional processes of saline stress, which affect the liquid assimilation of $\mathrm{CO}_{2}$, inhibiting leaf expansion and decrease the area destined for the photosynthetic process (Taiz et al., 2017, Dias et al., 2018).

In the same culture, Sousa et al. (2016) observed reductions in photosynthesis with increasing salt concentration in irrigation water. Similarly, Feijão et al. (2011) found that saline stress reduced photosynthesis in plants of sorghum under greenhouse conditions.

The plants showed lower values of transpiration rates with the addition of salts in the irrigation water (Figure 2B), where there were linear decreases of $23.08 \%$ of the water from high to low salinity. Corroborating information from Lima et al. (2010), where they mention that the stomatal behavior regulates the transpiration demand that the leaves are potentially subject to, controlling their loss of water to the environment, in the form of water vapor.

Gomes et al. (2015) evaluating physiological responses in sunflower plants (Helianthus annuus L.) found that the transpiration reduced linearly as the irrigation water salinity increased. Similarly, Sousa et al. (2016) noted a reduction in the transpiration values of corn plants cultivated in a protected environment, with waters of increasing salinity.

The stomatal conductance (gs) decreased linearly with the increase in irrigation water salinity (Figure 1C), from 0.32 to $0.21 \mathrm{~mol} \mathrm{~m}^{-2} \mathrm{~s}^{-1}$, exhibiting a reduction of $0.11 \mathrm{~mol} \mathrm{~m}^{-}$ ${ }^{2} \mathrm{~s}^{-1}$ between the lowest $\left(1.0 \mathrm{dS} \mathrm{m}^{-1}\right)$ and the highest saline water treatment $\left(5.0 \mathrm{dS} \mathrm{m}^{-1}\right)$.

To avoid excessive water loss, plants under salt stress tend to close their stomata, as there is a greater difficulty of the roots to absorb water, due to the increase of the osmotic potential (Gomes et al., 2015). Stomatal closure causes a reduction in the assimilation of $\mathrm{CO}_{2}$ and consequently lower photosynthetic rates (Taiz et al., 2017).

Similar results were found by Sousa et al. (2016) when irrigating corn plants with potted salt water. Likewise, Gomes et al. (2011) and Omoto et al. (2012) also showed a negative effect of saline stress on stomatal conductance in corn plants.

Due to the reduction in transpiration values, as expected, the leaf temperature $\left(\mathrm{T}_{\mathrm{f}}\right)$ increased as the concentration of the salts increased in the irrigation water, adjusting to an increasing linear model (Figure 1D). Transpiration contributes to reduce leaf temperature (cooling), which is crucial during the day when leaf is absorbing large amounts of energy from the sun (Machado et al., 2010).

The leaf temperature ranged from $30.88{ }^{\circ} \mathrm{C}$ to $32.92{ }^{\circ} \mathrm{C}$ in the low salinity water to the high salinity water respectively, i.e. there was an increase of $6.64 \%$. The values of leaf temperature up to ECw of $3 \mathrm{dS} \mathrm{m}^{-1}$ were lower than the values found by Lima et al. (2021) in peanut plants (Arachis Ypogeae, L.) irrigated with saline water. Similar results to the present study were found by Coelho et al. (2018) in 10 genotypes of sorghum irrigated with saline water.

The linear decreasing model was the best fit for the internal $\mathrm{CO}_{2}$ concentration variable, in which the increase of the salt concentration in the water affected negatively the maize plants. The internal $\mathrm{CO}_{2}$ concentration had a reduction of $178.52 \mu \mathrm{mol} \mathrm{m} \mathrm{m}^{-2} \mathrm{~s}^{-1}$ when low salinity water was used, and $134.85 \mu \mathrm{mol} \mathrm{m} \mathrm{m}^{-2} \mathrm{~s}^{-1}$ when water was used with salinity of $5.0 \mathrm{dS} \mathrm{m}^{-1}$ (Figure 1E). Therefore, there was a reduction of $24.46 \%$.

The partial closure of stomata causes a decrease in internal $\mathrm{CO}_{2}$ concentration, especially when photosynthesis is maintained, even at low levels (Machado et al., 2010). Omoto et al. (2012) concluded that the $\mathrm{NaCl}$ solution reduced the internal $\mathrm{CO}_{2}$ concentration in corn plants. Similar result of the present study was found by Souza et al. (2011) in cowpea (Vigna unguiculata) irrigated with saline water.

The water use efficiency responded in a polynomial quadratic manner as a function of the increase in salinity in the irrigation water (Figure 1F), where the highest value occurred in water of $3.13 \mathrm{dS} \mathrm{m}^{-1}$. It can be stated that the plant saved water use in both normal and saline conditions to produce dry matter.

The answer may be related to the $\mathrm{C} 4$ metabolism characteristic of corn, where high rates of photosynthesis occur under conditions of low availability of $\mathrm{CO} 2$ caused by stomata closure (Taiz et al., 2017).

Melo et al. (2017) reported that water use efficiency increased in pepper plants after 15 days of irrigation with water of high electrical conductivity. Similarly, Coelho et al. (2018) noted that water use efficiency in 10 sorghum genotypes increased with salinity, demonstrating the crop ability to adapt to salt environment and maintain a positive photosynthesis rate, even under conditions that limit water absorption.

Table 3 shows the values of the mean squares and the significance of nutrient contents $(\mathrm{N}, \mathrm{P}, \mathrm{K}, \mathrm{Ca}$ and $\mathrm{Mg}$ ) found in maize leaves, according to five levels of salinity $\left(1.0 ; 2.0 ; 3.0 ; 4.0\right.$ and $\left.5.0 \mathrm{dS} \mathrm{m}^{-1}\right)$ of the irrigation water.

Increased salinity of irrigation water affected negatively nitrogen levels in maize leaves, with a $16.48 \%$ reduction in water from 1.0 to $5.0 \mathrm{dS} \mathrm{m}^{-1}$ (Figure $2 \mathrm{~A}$ ), the linear model being the one that best fit. This response may be due to the presence of chlorine in the salts of the irrigation water causing an antagonistic effect with the nitrogen and deficiency of this element in maize plants.

Similarly, Ferreira et al. (2007) found that saline stress significantly affected nitrogen levels in leaves of corn 
plants at 90 and 120 DAS. In bean plants, Neves et al. (2009) also observed decreases in the nitrogen content of the leaves during the crop cycle.

In figure $2 \mathrm{~B}$, the phosphorus contents varied according to the quadratic polynomial model, obtaining a maximum value of $2.24 \mathrm{~g} \mathrm{~kg}^{-1}$ for the electrical conductivity of the irrigation water of $2 \mathrm{dS} \mathrm{m}^{-1}$. The ECw of $5 \mathrm{dS} \mathrm{m}^{-1}$ was the most affected by the salts present in the irrigation water, leading to the deficiency of this element in the maize crop, that is, causing damages in the phosphorus functions.

Table 3: Summary of the variance analysis for the nitrogen $(\mathrm{N})$, phosphorus $(\mathrm{P})$ and potassium $(\mathrm{K})$ variables in maize plants irrigated with salt water

\begin{tabular}{lcccccc}
\hline \multicolumn{7}{c}{ Mean square } \\
\hline SV & DF & N & P & K & Ca & Mg \\
\hline Blocks & 3 & $4.38^{\text {ns }}$ & $0.05^{\text {ns }}$ & $3.90^{\text {ns }}$ & 1.62 & 1.2 \\
Treatment & 4 & $4.35^{*}$ & $0.14^{*}$ & $37.36^{* *}$ & $8.82^{* *}$ & $7.32^{* * *}$ \\
Residue & 12 & 1.3 & 0.03 & 2.8 & 0.75 & 0.54 \\
Total & 19 & - & - & - & & 3.87 \\
MG & - & 13.04 & 2.04 & 12.518 & 17.78 & 19.21 \\
\hline CV $(\%)$ & - & 8.74 & 8.08 & 13.36 & 17
\end{tabular}

$\mathrm{SV}$, source of variation; $* *$ and $*$ Significant at 0.01 and 0.05 by the $\mathrm{F}$ test, respectively; DF, degree freedom; ns = not significant; MG, general mean; $\mathrm{CV}$, coefficient of variation.
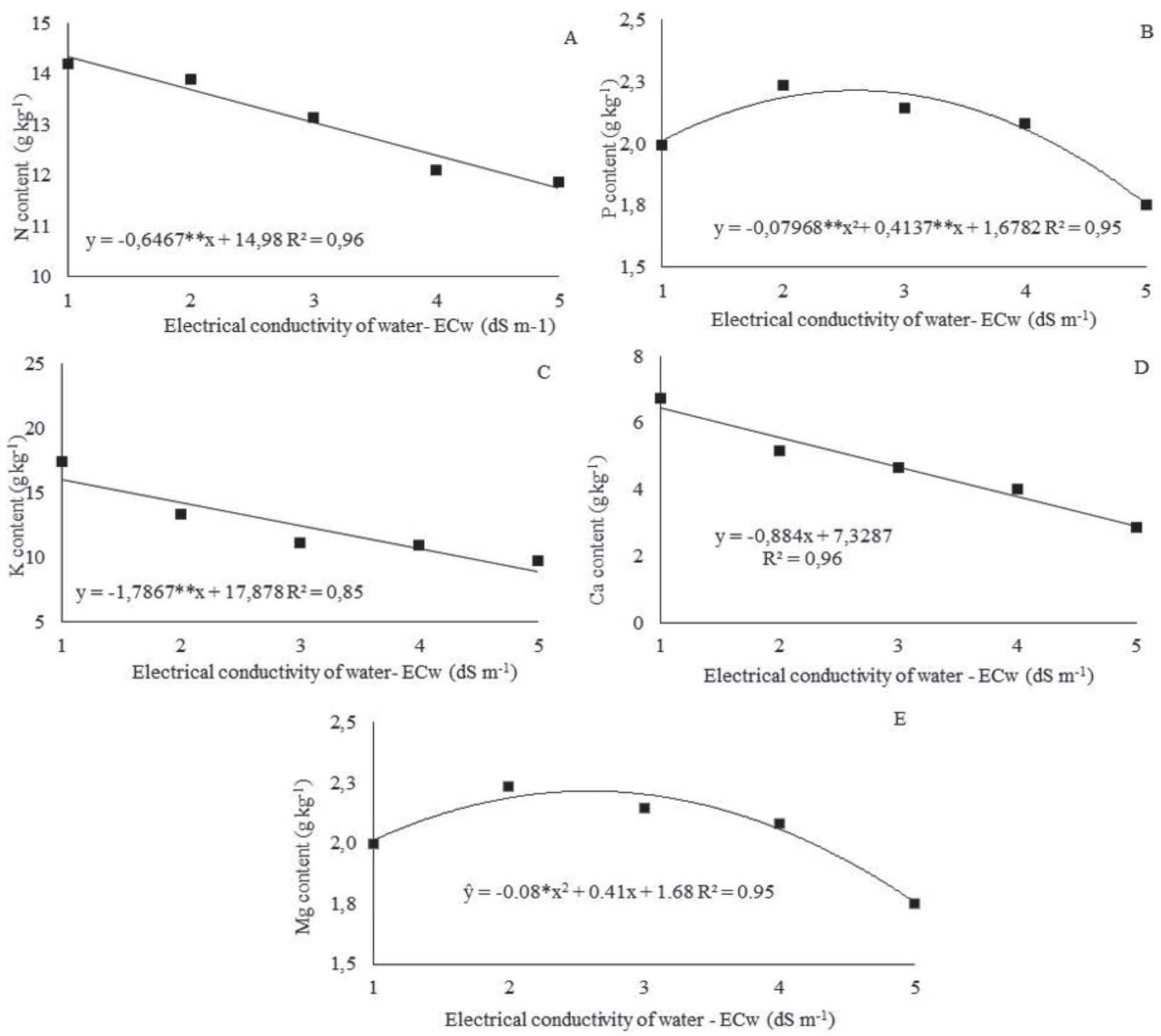

Figure 2: Nitrogen, phosphorus, potassium, calcium and magnesium contents in maize leaves irrigated with saline water at 110 DAS. 
Contrary to this study, Sousa et al. (2010) showed that saline stress did not influence P levels in leaf limy of corn crop. Likewise, Ferreira et al. (2007) also found a reduction in phosphorus levels in corn leaves.

Although it is a necessary element, when in excess can express characteristics detrimental to the production, such as the presence of dark-red spots on old leaves and the deficiency of cationic micronutrients such as $\mathrm{Zn}$ (zinc), $\mathrm{Cu}$ (copper), $\mathrm{Fe}$ (iron) and $\mathrm{Mn}$ (manganese), occurring by the depression of $\mathrm{CO}_{2}$ fixation and the synthesis of starch.

In figure $2 \mathrm{C}$, the linear model was the one that best fit the data, revealing that the increase of the irrigation water salinity affected negatively the potassium contents in the maize leaves, with a $44.11 \%$ reduction in water from 1.0 to $5.0 \mathrm{dS} \mathrm{m}^{-1}$ thus affecting the potassium functions for the crop development.

Similarly, Sousa et al. (2010) concluded that the potassium content in corn leaves, corn grains and corn sabots was reduced with increasing saline irrigation water levels. Garcia et al. (2007) shows that soil salinity also significantly affects the potassium contents in the leaves of corn at $120 \mathrm{DAS}$, linearly decreasing its values with the increase of soil salinity levels.

As seen in figure 2D, the Ca content was negatively affected by the irrigation water. When irrigated with water of $5 \mathrm{dS} \mathrm{m}^{-1}$, the Ca content decreased by $54.81 \%$ in relation to the treatment with water of $1 \mathrm{dS} \mathrm{m}^{-1}$. Although calcium chloride has been used in water, its proportion in relation to sodium chloride is much lower, however, the presence of sodium may have affected the bioavailability of calcium.

Similarly, Song et al. (2017) working with perennial ryegrass accessions under salinity stress, found a reduction in the concentration of $\mathrm{Ca}^{+}$in the treatment with high salinity. On the other hand, Coelho et al. (2017), when studying the accumulation of nutrients in forage sorghum genotypes under salinity, found an increase in the $\mathrm{Ca}^{+}$leaf content.

The $\mathrm{Mg}$ values were adjusted to the quadratic polynomial model (Figure 2E), with a maximum value of $2.21 \mathrm{~g} \mathrm{~kg}^{-1}$, for an ECw of $2.56 \mathrm{dS} \mathrm{m}^{-1}$. Possibly, the decrease in the leaf content of $\mathrm{Mg}$ is related to an inhibition of the biological functions of the roots, caused by the high concentration of salts in the irrigation water (Ahmadi \& Souri, 2018).

In the cowpea culture, Sá et al. (2021) also observed a quadratic behavior in the concentration of $\mathrm{Mg}$ in the area, noting an increase up to the electrical conductivity of the water of 1.34 and $1.10 \mathrm{dS} \mathrm{m}^{-1}$, with subsequent reductions up to the value of $4.5 \mathrm{dS} \mathrm{m}^{-1}$.

\section{CONCLUSIONS}

The saline stress due to saltwater irrigation leads to a reduction in photosynthesis, stomatal conductance, internal $\mathrm{CO}_{2}$ concentration and transpiration in field maize plants.
Foliar temperature and water use efficiency increased as a result of increased salinity levels in irrigation water, but in the case of water use efficiency this increase occurred until the electrical conductivity of the water of $4 \mathrm{ds} \mathrm{m}^{-1}$.

Salt stress reduces the levels of N, P, K, Ca and Mg mineral elements in maize leaves.

\section{CONFLICT OF INTEREST}

The authors declare that there is no conflict of interest regarding the publication of this scientific article.

\section{REFERENCES}

Alvares CA, Stape JL, Sentelhas PC, Gonçalves JLM \& Sparovek G (2013) Köppen's climate classification map for Brazil. Meteorologische Zeitschrift, 22:711-728.

Ahmadi M \& Souri MK (2018) Growth and mineral content of coriander (Coriandrum sativum L.) plants under mild salinity with different salts. Acta Physiologiae Plantarum, 40:1-8.

Ayers RS \& Westcot DW (1999) A qualidade da água na agricultura. $2^{\text {nd }}$ ed. Campina Grande, UFCG. 153p.

Coelho DS, Simões WL, Salviano AM, Souza MA \& Santos JE (2017) Acúmulo e distribuição de nutrientes em genótipos de sorgo forrageiro sob salinidade. Revista Brasileira de Milho e Sorgo, 16: 78-192.

Coelho DS, Simões WL, Salviano AM, Mesquita AC \& Alberto KC (2018). Gas exchange and organic solutes in forage sorghum genotypes grown under different salinity levels. Revista Brasileira de Engenharia Agrícola e Ambiental, 22:231-236.

Cruz RIF, Silva GF, Silva MM, Silva AHS, Júnior JAS \& Silva EFF (2021) Productivity of irrigated peanut plants under pulse and continuous dripping irrigation with brackish water. Revista Caatinga, 34:208-218

Dias AS, Lima GS, Sá FVS, Gheyi HR, Soares LAA \& Fernandes PD (2018) Gas exchanges and photochemical efficiency of West Indian cherry cultivated with saline water and potassium fertilization. Revista Brasileira de Engenharia Agrícola e Ambiental, 22:628-633.

Doorenbos J \& Kassam AH (1994). Efeito da água no rendimento das culturas. Campina Grande, UFCG. 306p.

Feijão AR, Silva JCB, Marques EC, Prisco JT \& Gomes-filho E (2011) Efeito da nutrição de nitrato na tolerância de plantas de sorgo sudão à salinidade. Revista Ciência Agronômica, 42:675683.

Ferreira PA, Garcia GO, Neves JCL, Miranda GV \& Santos DB (2007) Produção relativa do milho e teores foliares de nitrogênio, fósforo, enxofre e cloro em função da salinidade do solo. Revista Ciência Agronômica, 38:7-16.

Freire MHC, Sousa GG, Souza MVP, Ceita EDR, Fiusa JN \& Leite KN (2018) Emergence and biomass accumulation in seedlings of rice cultivars irrigated with saline water. Revista Brasileira de Engenharia Agrícola e Ambiental, 22:471-475.

Garcia GO, Ferreira PA, Miranda GV, Neves JCL, Moraes WB \& Santos DB (2007) Teores foliares dos macronutrientes catiônicos e suas relações com sódio em plantas de milho sob estresse salino. Idesia, 25:93-106.

Gomes KR, Amorim AV, Ferreira FJ, Filho FLA, Lacerda CF \& Gomes-filho E (2011) Respostas de crescimento e fisiologia do milho submetido a estresse salino com diferentes espaçamentos de cultivo. Revista Brasileira de Engenharia Agrícola e Ambiental, $15: 365-370$ 
Gomes KR, Sousa GG, Lima FA, Viana TVA, Azevedo BM \& Silva GL (2015) Irrigação com água salina na cultura do girasso (Helianthus annuus 1.) em solo com biofertilizante bovino. Irriga, 20:680-693.

Lima ABS, Santos MF, Oliveira, ML, Sousa GG, Filho PFM \& Luz LN (2021) Physiological responses of inoculated and uninoculated peanuts under saline stress. Revista Ambiente \& Água, 16:e2643.

Lima MA, Bezerra MA, Gomes-filho E, Pinto CM \& Enéas-filho J (2010) Trocas gasosas em folhas de sol e sombreadas de cajueiro anão em diferentes regimes hídricos. Revista Ciência Agronômica, 41:654-663.

Machado DFSP, Machado EC, Machado RS \& Ribeiro RV (2010) Efeito da baixa temperatura noturna e do porta-enxerto na variação diurna das trocas gasosas e na atividade fotoquímica de laranjeira 'valência'. Revista Brasileira de Fruticultura, 32:351359 .

Malavolta E, Vitti GC \& Oliveira SA (1997). Avaliação do estado nutricional das plantas: princípios e aplicações. $2^{\text {nd }}$ ed. Piracicaba, Associação Brasileira para Pesquisa da Potassa e do Fosfato. $319 \mathrm{p}$.

Melo HFD, Souza ER, Duarte HHF, Cunha JC \& Santos HRB (2017) Gas exchange and photosynthetic pigments in bell pepper irrigated with saline water. Revista Brasileira de Engenharia Agrícola e Ambiental, 21:38-43.

Neves ALR, Lacerda CF de, Guimarães FVA, Gomes Filho E \& Feitosa DRC (2009) Trocas gasosas e teores de minerais no feijão-de-corda irrigado com água salina em diferentes estádios. Revista Brasileira de Engenharia Agrícola e Ambiental, 13:873881

Omoto E, Taniguchi M \& Miyake H (2012) Adaptation responses in $\mathrm{C} 4$ photosynthesis of maize under salinity. Journal of Plant Physiology, 169:469-477.

Pereira JV, Viana TVA, Sousa GG, Chagas KL, Azevedo BM, \& Pereira C (2019) Physiological responses of lima bean subjected to salt and water stresses. Revista Brasileira de Engenharia Agrícola e Ambiental, 23:959-965.

Rhoades JD, Kandiah A \& Mashali AM (2000) Uso de águas salinas para a produção agrícola. Campina Grande, UFPB. 117p.
Sá FVDS, Silva IE, Neto MF, Lima YB, Paiva EP \& Gheyi HR (2021) Phosphorus doses alter the ionic homeostasis of cowpea irrigated with saline water. Revista Brasileira de Engenharia Agrícola e Ambiental, 25:372-379.

Silva FASE \& Azevedo CAV (2009) Principal Components Analysis in the Software Assistat-Statistical Attendance. In: World Congress on Computers in Agriculture, 7, Reno. American Society of Agricultural and Biological Engineers.

Song X, Wang SM \& Jiang Y (2017) Genotypic variations in plant growth and nutritional elements of perennial ryegrass accessions under salinity stress. Journal of the American Society for Horticultural Science, 142:476-483.

Sousa GG, Lacerda CF, Cavalcante LF, Guimarães FVA, Bezerra MEJ \& Silva GL (2010) Nutrição mineral e extração de nutrientes de planta de milho irrigada com água salina. Revista Brasileira de Engenharia Agrícola e Ambiental, 14:1143-1151.

Sousa GG, Viana TVA, Silva GL, Dias CN \& Azevedo BM (2016). Interação entre salinidade e biofertilizante de caranguejo na cultura do milho. Magistra, 28:44-53.

Sousa GG, Fiusa JN, Leite KN, Soares SC \& Silva GL (2017) Água salina e biofertilizante de esterco bovino na cultura do gergelim. Revista Agropecuária Técnica, 38:116-125.

Sousa HC, Sousa GG, Lessa CI, Lima AFDS, Ribeiro RM, \& Rodrigues FHDC (2021) Growth and gas exchange of corn under salt stress and nitrogen doses. Revista Brasileira de Engenharia Agrícola e Ambiental, 25:174-181.

Souza RP, Machado EC, Silveira JAG \& Ribeiro RV (2011) Fotossíntese e acúmulo de solutos em feijoeiro caupi submetido à salinidade. Pesquisa Agropecúaria Brasileira, 46:586-592.

Taiz L, Zeiger E, Moller I \& Murphy A (2017) Fisiologia e desenvolvimento vegetal. $6^{\text {th }}$ ed. Porto Alegre, Artmed. 888p.

Tedesco MJ, Gianello C, Bissani CA, Bohnen H \& Volkweiss SJ (1995) Análise de solos, plantas e outros materiais. Porto Alegre, UFRGS. 174p. (Technical Bulletin, 5).

Teixeira PC, Donagemma GK, Fontana A \& Teixeira WG (2017) Manual de métodos de análise de solo. $3^{\text {rd }}$ ed. Brasília, Embrapa Informação Tecnológica. 573p. 